\title{
MEGOLDÁSVÁLTOZATOK FELSŐ VÉGTAGI BÉNULTAK ÁLTAL HASZNÁLHATÓ MECHANIKUS KORMÁNYSZERKEZET KONCEP- CIONÁLIS TERVEZÉSE SORÁN
}

\author{
Kántor Kristóf \\ BSc. géptervezö hallgató, Miskolci Egyetem, Gép-és Terméktervezési Intézet \\ Cím: 3515 Miskolc, Miskolc-Egyetemváros, e-mail: kksalieri@gmail.com \\ Bihari János \\ egyetemi docens, Miskolci Egyetem, Gép-és Terméktervezési Intézet \\ Cím: 3515 Miskolc, Miskolc-Egyetemváros,e-mail: machbj@uni-miskolc.hu
}

\begin{abstract}
Absztrakt
A cikkben a tervezés elsö néhány lépését mutatjuk be. A munka a probléma megismerésével kezdödik, majd a probléma kezelésére készült megoldások kutatásával folytatódik. Az ebben a fejezetben talált termékek és szabadalmak elemzését követöen, az ott tapasztalt elönyök és hátrányokat felhasználva megoldásváltozatok készülnek. A folyamat eredményei azok a koncepciók, melyek közül az értékelés során a legjobb megoldást lehet kiválasztani.
\end{abstract}

Kulcsszavak: koncepcionális tervezés, koncepcióalkotás, megoldásváltozat

\begin{abstract}
In the article we show the first few steps of the designing process. The task is started with the recognition of the problem then continued with the research of the existing solutions. After the analyzing of the discovered products and patents we make some solution variants using the pros and cons of the found solutions. At the end of the solution finding the winner solution belongs to those solutions which are the outcomes of this whole process.
\end{abstract}

Keywords: conceptual design, concept creating, solution variant

\section{Bevezetés}

A mérnöki munka feladata, hogy a müszaki tudományt felhasználva egy müszaki problémára optimális megoldást adjon. A folyamat a probléma elemzésével kezdődik. Egy mérnöknek az adott problémáról átfogó képpel kell rendelkeznie. Ez kifejezetten nehéz lehet olyan gyógyászati segédeszközök tervezésénél, amelyeket bénult, vagy amputált betegek használnak. A munka elemzési fázisában elengedhetetlen a kommunikáció a megrendelővel, valamint nagy segítséget jelent az internetes fórumok és cikkek olvasása. A feladat feltárását követően meg kell nézni a problémára született megoldásokat. A szabadalmak és a piacon fellelhető termékek elemzése során a müködésük mellett fontos megfigyelni, hogy milyen igényeket tudnak kielégíteni. Előbbi megfigyelésböl funkcióábrát, utóbbiból követelményjegyzéket készíthetünk. A követelményjegyzék a teljes tervezési folyamat egyértelmủ alapjaként szolgál, így kiemelkedő a jelentősége. 


\section{A téma feltárása}

A különböző olyan bénulásos betegségek, amelyek a felső végtagokat érintik, kihatással vannak a beteg mindennapi életére. Az önálló öltözködés, étkezés, fogmosás stb. is nehézséget okozhat, a gépjármüvezetést pedig különösen akadályozzák az ilyen betegségek. Habár a bénulások mozgásképesség szempontjából is sokfélék lehetnek, a finom mozgások kiesésétől egészen a teljes kar mozdulatlanságáig, elmondható az, hogy az ilyen betegségekben érintettek nem képesek a szokásos kialakítású gépjármüvek vezetésére.

A problémára az első megoldást az előző évszázad közepén dolgozták ki. (1. ábra) A piacon fellelhető, modern eszközök müködésüket és gyakran felépítésüket tekintve ehhez képest nem változtak jelentősen. A kinematikai lánc egy forgótárcsával (89) és lábkengyellel (123) kezdődik. A tárcsa tengelye pedig valamilyen rugalmas hajtással áthajt a kormányrúdon (20) elhelyezett hajtáselemre (28), így múködtetve a kormányszerkezetet.

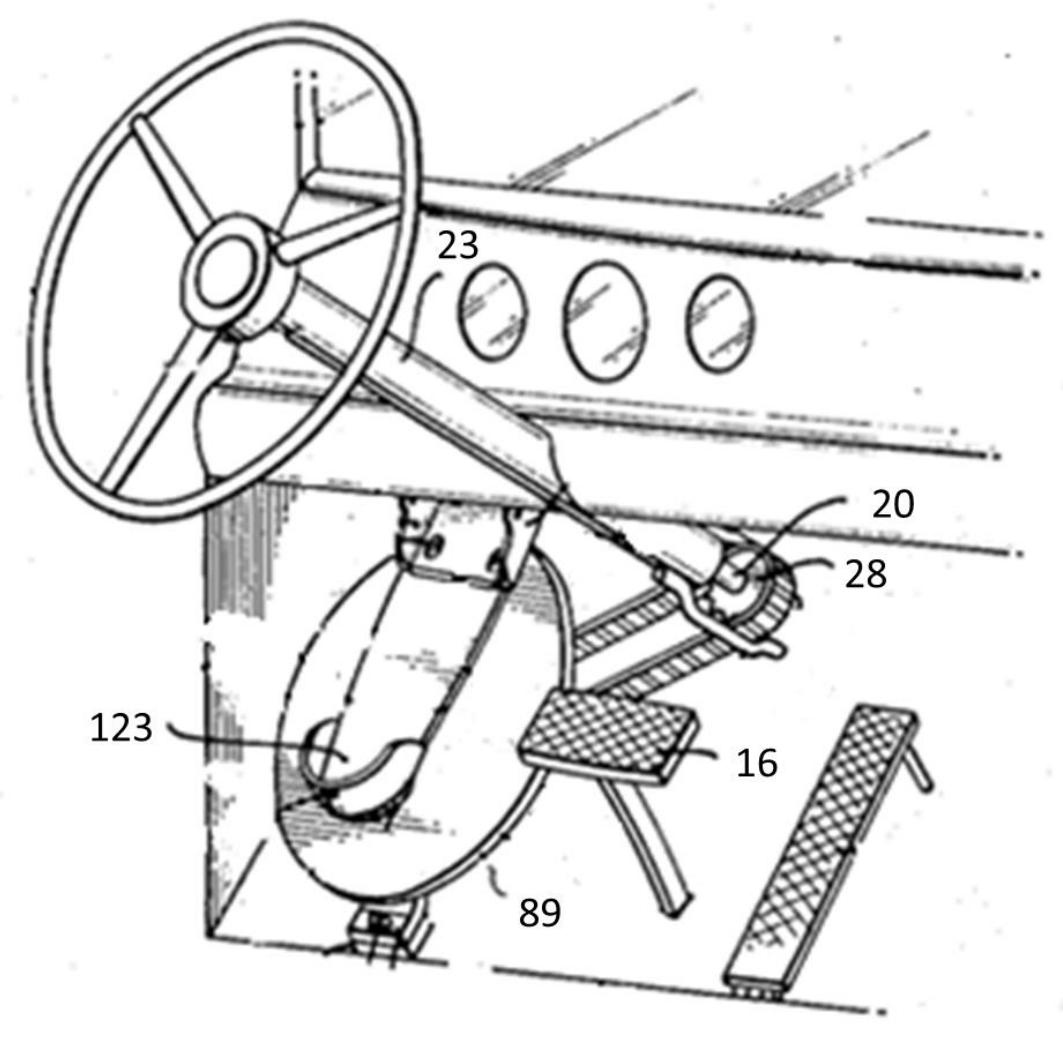

1. ábra. David Kope szabadalma[4] 


\section{A szabadalom- és piackutatás eredménye}

A kutatás során talált eszközöket négy egységre oszthatjuk, melyek részfunkciók is egyben: mozgásindítás, mozgásátadás, kormánymű és kerék. A tervezés során az első kettő egységgel kell foglalkozni, mely a kengyelt, a forgótárcsát, valamint annak tengelye és a kormányrúd között található kinematikai láncot foglalja magába. A kormánymű azon belül is a kormányoszlop csak útmutatást ad a koncepcióalkotás során. A jármü eredeti kormányszerkezetén a lehető legkisebb mértékü átalakítás szükségességét szeretném elérni.

A funkciók megállapítása mellett a kialakítások megfigyelése is fontos. Ezek előnyeit és hátrányait célszerü összegyüjteni. A megoldás kialakításának elemzése során nem csak a fizikai jellemzőket kell figyelembe venni, hanem olyan tulajdonságokat is, mint a használhatóság, gyárthatóság, gazdasági jellemzök, stb.

\section{Megoldásváltozatok készítése}

A megoldásváltozatok készítése alapvetően két irányt foglal magában, amelyek később találkoznak majd: a forgótárcsa, valamint az áthajtás létrehozását.

A tárcsák a piacon fellelhető megoldásoknál gyakorlatilag pár esettől eltekintve azonosak. A kivételek esetén olyan tárcsáról beszélhetünk, ami autókormány alakú, vagy egy osztókör mentén több furattal rendelkező tárcsa. Ezeket a nagylábujj segítségével forgatják a soförök, mely meglátásom szerint balesetveszélyes és kényelmetlen lehet. A nagyobb számban használt tömör tárcsák esetén a lábfejet vagy egy tartókengyelbe, vagy egy rögzített cipőbe helyezik. A cipő felvétele nehézségeket okozhat, így a koncepciók megalkotásánál a tartókengyel használata mellett döntöttem.

\subsection{Az áthajtás megoldásai}

Az áthajtás során a tárcsa tengelyének forgó mozgását kell a kormányrúdra átvinni. Ennek legegyszerübb megoldása az 1. ábra bemutatott rugalmas hajtás használata. A fö probléma az, hogy a mai modern autókban a kormányoszlop nem egyenes, hanem középvonala akár több ponton is megtörik [3]. Ezeket a töréseket kardáncsuklókkal oldják meg. Egyes típusok esetén a gyárilag elhelyezett kardáncsukló a tüzfal utastér felőli oldalán, közvetlenül a padlólemez elött helyezkedik el. Ennélfogva a rugalmas hajtás egytengelyüsége nem biztosítható egyszerü felépítés mellett.

A probléma megoldására lehetőség, ha az áthajtást máshogyan helyezzük el a kormányrúdon. A kormányrúd mellett rendelkezésre álló helytől függően két hajtástípus alkalmazható:

- rugalmas hajtás

- fogaskerékhajtás

A fogaskerékhajtás esetén a tárcsa (a.1) forgó mozgását a tengelyrendszeren (a.8) keresztül lehet eljuttatni az áthajtó fogaskerékhez (a.3). (2. ábra a)) A tengelyrendszer térben nagyobb fokú szabadságot nyújt, azonban a tengelyek csapágyazása bonyolult, és a rendszer sok elemből áll. Emellett a kormányrúd (a.5) átalakítása és kiszerelése nélkül nem rögzíthető a hajtott fogaskerék (a.4).

A tengelyrendszer problémáit ki lehet küszöbölni flexibilis tengely (b.8) használatával. (2. ábra b)) Azonban az elvezetése gondot okozhat, mivel az átmérö függvényében csökken a hajlíthatósága, a nyomatékátadása nem minden szögnél pontosan azonos, valamint a beszerzése is nehézkes lehet, így gazdasági problémákat is felvet. A flexibilis tengely csatlakoztatására tengelykapcsolók (b.9) használata szükséges lehet. 


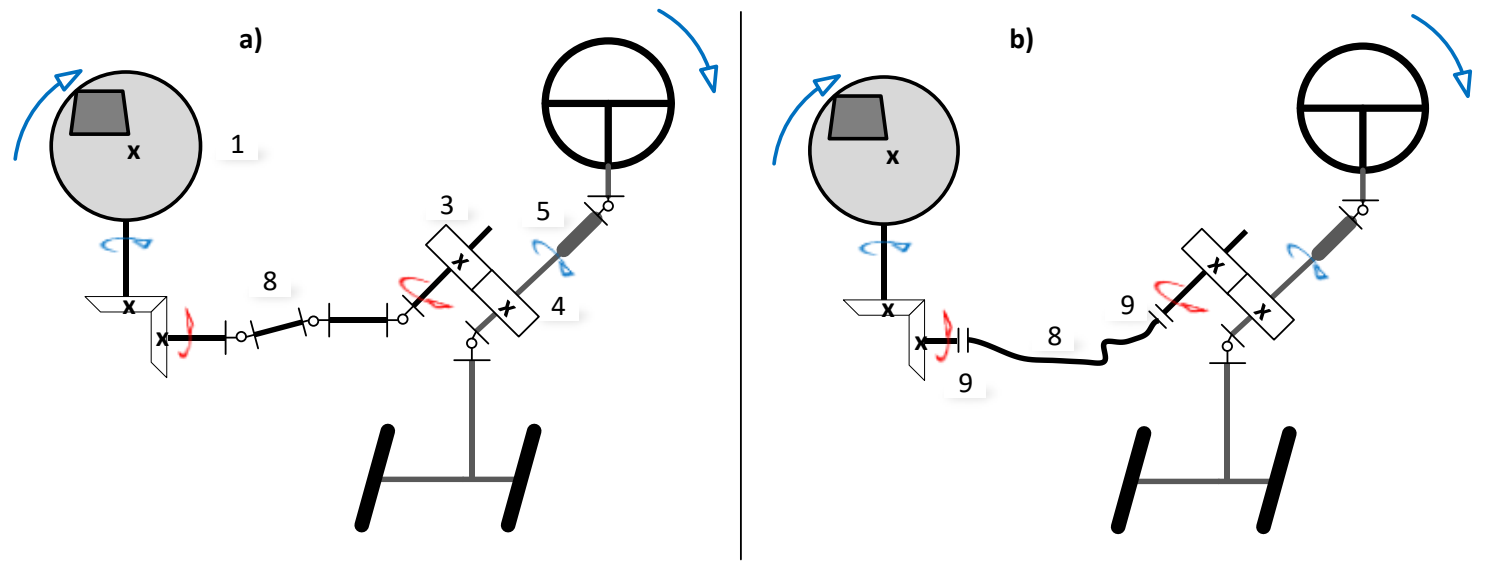

2. ábra. Fogaskerekes áthajtás: a) tengelyrendszerrel, b) felxibilis tengellyel

Rugalmas hajtás esetében a hajtás egytengelyüségét egy közbülső előtéttengellyel lehet megoldani. (3. ábra) Az előtéttengelyt (6) úgy kell beépíteni, hogy párhuzamos legyen azzal a kormányrúdszakasszal (5), ahol a hajtott szíjtárcsa vagy lánckerék (8) rögzítésre kerül. Amennyiben a hajtott hajtáselem (8) két félből, agyas kivitelben készül, úgy a kormányoszlop kiszerelése nem szükséges, csökken az átalakítás munkaideje, így a szerelés díja is csökkenhet. A két rugalmas hajtás (9 és 10) különböző is lehet, azonban az egyszerübb szerelés érdekében célszerü, ha azonos típusúak.

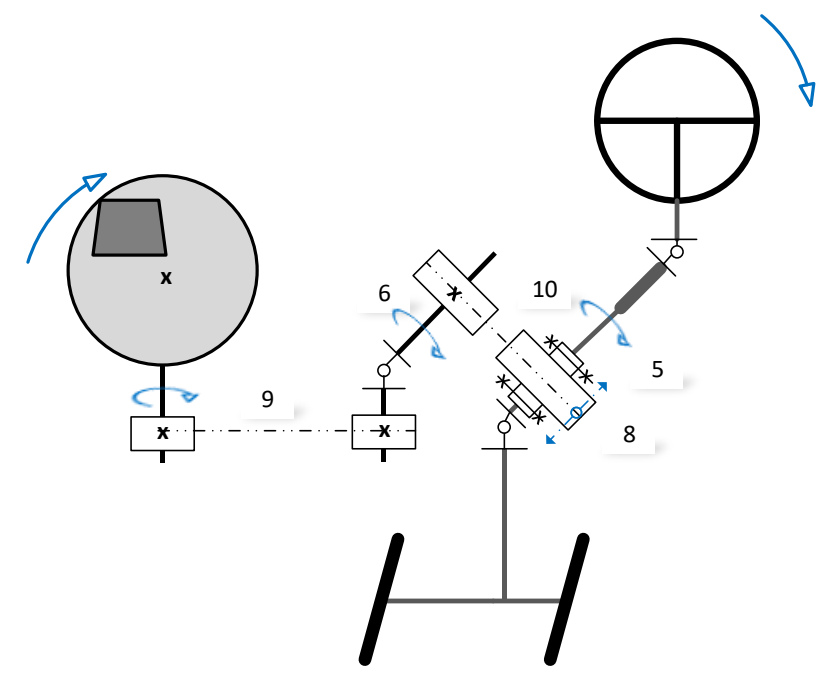

3. ábra. Rugalmas áthajtás elötéttengelyt alkalmazva

\section{5. Összefoglalás}

A koncepcióalkotási folyamat minden részletét a terjedelem miatt ebben a cikkben nem lehet ismertetni, de egy rövid összefoglalóval tudtam szolgálni, hogy a kutatómunka során hogyan jutottam el a koncepciók megalkotásához. A folyamat bemutatása mellett a megoldásváltozatok különlegességeire 
is kitértem, és arra, hogy azok hogyan és miért alakultak ki. Az elkészült koncepciók alkalmazása nem minden esetben célravezető. Azokban az esetekben, ahol a 2. fejezetben bemutatott megoldás alkalmazható ezt célszerü beépíteni. Az elkészült megoldásváltozatok kialakítása és funkcióiknak listája a jármü kialakításától és a megrendelő igényeitől függően változhat.

\section{Köszönetnyilvánítás}

A cikkben ismertetett kutató munka az EFOP-3.6.1-16-2016-00011 jelü „Fiatalodó és Megújuló Egyetem - Innovatív Tudásváros - a Miskolci Egyetem intelligens szakosodást szolgáló intézményi fejlesztése" projekt részeként - a Széchenyi 2020 keretében - az Európai Unió támogatásával, az Európai Szociális Alap társfinanszírozásával valósul meg.

\section{Irodalom}

[1] G. Pahl, W. Beitz, J. Feldhusen, K.H. Grote: Engineering Design: A systematic Approach. Springer Science+Business Media, London, 2007.

[2] Kamondi, L.- Sarka, F.- Takács, Á.: Fejlesztés-módszertani ismeretek. Elektronikus jegyzet. Készült: „Korszerủ anyag-, nano- és gépészeti technológiákhoz kapcsolódó müszaki képzési területeken kompetencia alapú, komplex digitális tananyag modulok létrehozása és on-line hozzáférésük megvalósítása" TÁMOP-4.1.2-08/1/a-2009-0001, Miskolc, 2011.

[3] Bihari János: Információs eszközök a gépjármüvekben, Géptervezők és Termékfejlesztők XX. országos Szemináriuma, 2004, 4.1 pont

[4] D. Kope: Vehicle Steering Device, US 2,856,223, 1956 